\title{
GEOCHRONOLOGY OF THE NIVAL-GLACIAL DEPOSITS OF THE UKRAINIAN CARPATHIAN MOUNTAINS
}

\section{N. N. KOVALYUKH, L. V. PETRENKO and V. V. KOVALENKO}

Institute of Radiogeochemistry of the Environment, Ukrainian Academy of Sciences 34 Palladin Av., Kiev 252142 Ukraine

\section{INTRODUCTION}

The few studies of the paleogeography of the Ukrainian Carpathians include the chronology of relief formation (Demeduke 1971), the development of vegetation (Malinovsky 1980) and the formation of the landscape (Miller 1961). Previous paleographic inferences were based on comparisons with natural alpine cycles (Koziy 1950, 1963; Tsys 1955, 1968; Tretyak and Kuleshko 1982). Neighboring areas to the west and south of the Ukrainian Carpathians are also insufficiently studied (Serebrany 1978).

Our study fits into current scientific research on the geochronology of continental glaciation, as set forth by the Sixth All-Union Conference. The aim of our investigation is to establish absolute ages for the major geological events of the Carpathians during the Holocene and the latter part of the Pleistocene. Such a time scale is necessary for estimating the temporal and spatial parameters of the youngest relief formations, the origins and dynamics of vegetation and the analyses of changing ecosystems. From these data, we are able to infer models of regional climatic change.

\section{DESCRIPTION OF THE NIVAL-GLACIAL MODEL}

The latest climate changes, represented in different stages of glacial, glaciofluvial and nival-fluvial sediments, are most discernible at the highest elevations of the Ukrainian Carpathians, the Chernogorsky Mountains. Figure 1 shows the area of our study, on the northern slopes of the Chernogorsky massif, where glaciation was most extensive. Figure 2 presents a model of nivalfluvial geosystems. The model offers informative data in the case of continuous, uninterrupted deposits. The system functions as follows:

1. Climate changes influence the local nival-glacial and floral regimes of alpine areas.

2. During cold and wet periods, snow and glaciers erode the slopes of the Carpathians.

3. Products of exaration are subjected to meltwater and gravitational drifting, accumulating in end moraines and forming strata of the friable mountain rock different from autochthonous fine-grained sediment.

4. Warm and dry climates bring glacial and snow exaration to a halt. Storage of fine-grained loess in deposits also terminates. The spread of marsh-meadow and shrub vegetation begins.

5. During subsequent cold periods and increasing humidity, fine-grained sediment rejuvenates. Buried under a layer of fine-grained sediment, the vegetation dies, condenses and forms peat.

6. Buried peat layers may be ${ }^{14} \mathrm{C}$ dated.

Intercalated layers of peat and fine-grained soil in areas where glacial debris accumulated provide evidence of prolonged periods of moisture, snow accumulations and frigid temperatures, which, in some areas, exceeded local annual glacial ablation (Tretyak 1978; Stoyko and Tretyak 1979). 


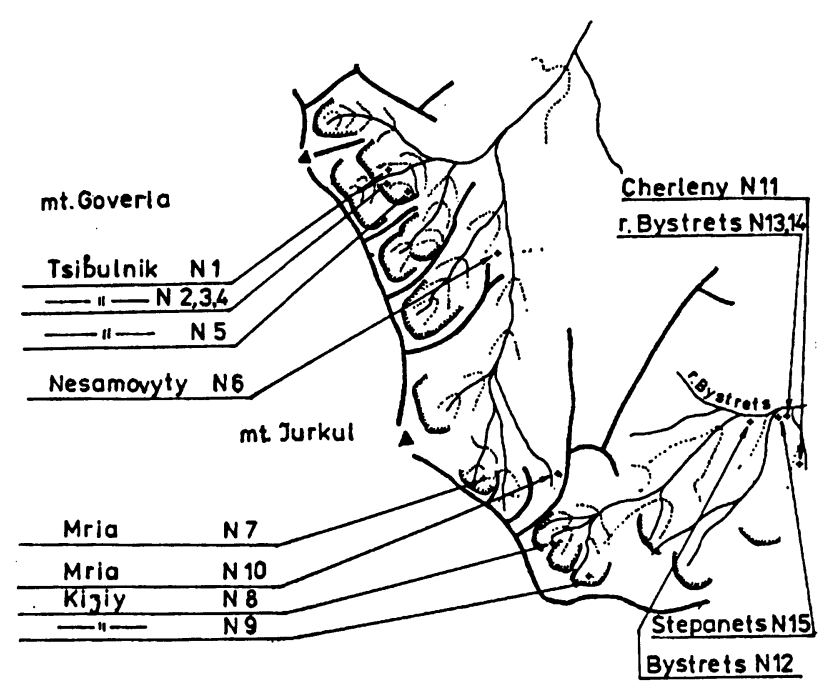

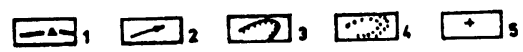

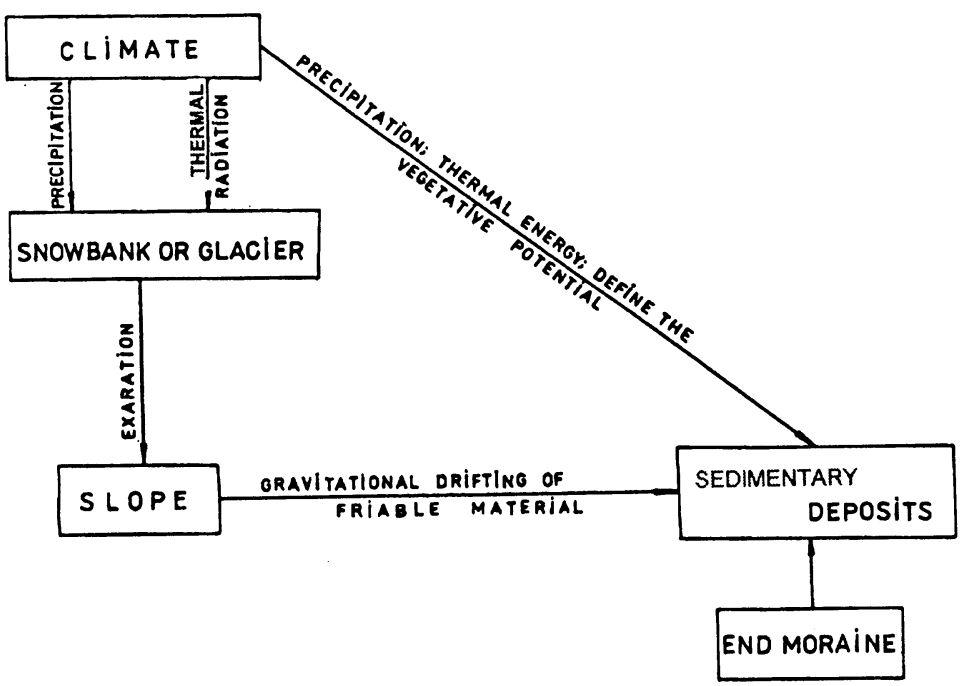

Fig. 1. Regional topography: 1. watersheds and summits; 2 . rivers and post-glacial lakes; 3 . old glacial lobes; 4 . terminal moraines; 5 . profiles

\section{RESULTS AND DISCUSSION}

Fig. 2. Conceptual model of the nival-glacial geosystem

We have studied four geosystems of this type (Fig. 1). Figure 3 shows ${ }^{14} \mathrm{C}$ dates and structure of nine profiles that we studied in end-moraine zones of alpine areas of the Ukrainian Carpathians. With this, we have established the first portion of the geochronology of the most recent nivalglacial formations in this area (Fig. 4). We dated fossil wood to define temporal boundaries of the warm periods. The depositional history and development of the Carpathian Mountain landscape described below, starting from the upper levels, are based on the ${ }^{14} \mathrm{C}$ dates that we obtained: 


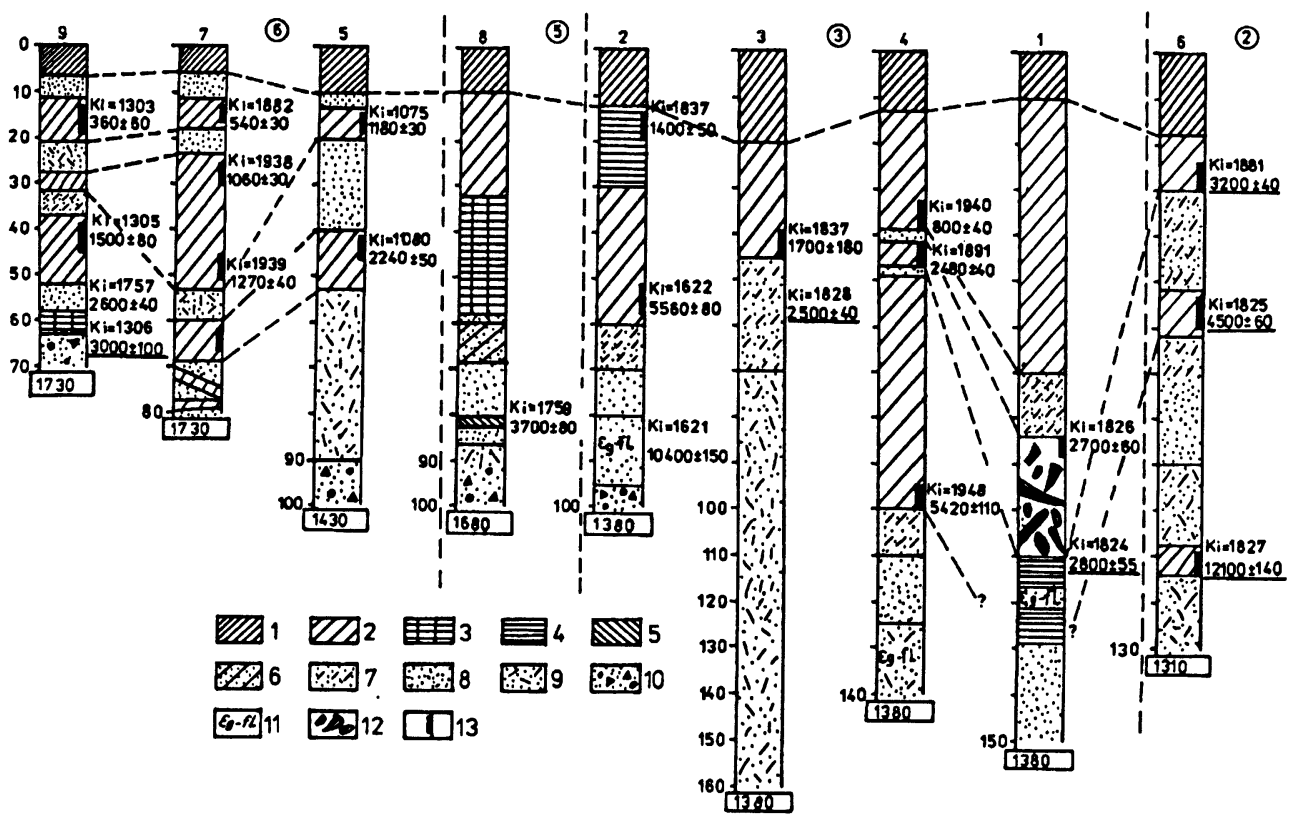

Fig. 3. Analysis of chronostratigraphic investigation of the alpine area of the Ukranian Carpathians. Key to symbols: 1. modern turf; 2 . buried peat; 3 . peat with remains of wood; 4 . peaty sediment; 5 . buried herbaceous vegetation; 6. peat with fine-grained sediment; 7. fine-grained sediment with organics; 8 . fine-grained sediment; 9. fine-grained sediment with gravel and wood; 10. morrainic deposits; 11 . buried rhizomes and caulescents of mare's tail; 12 . buried pine trunks; 13. sampling location. Circled nos. = fossil wood specimens. Figures below the stratigraphic columns $=$ depth $(m)$.

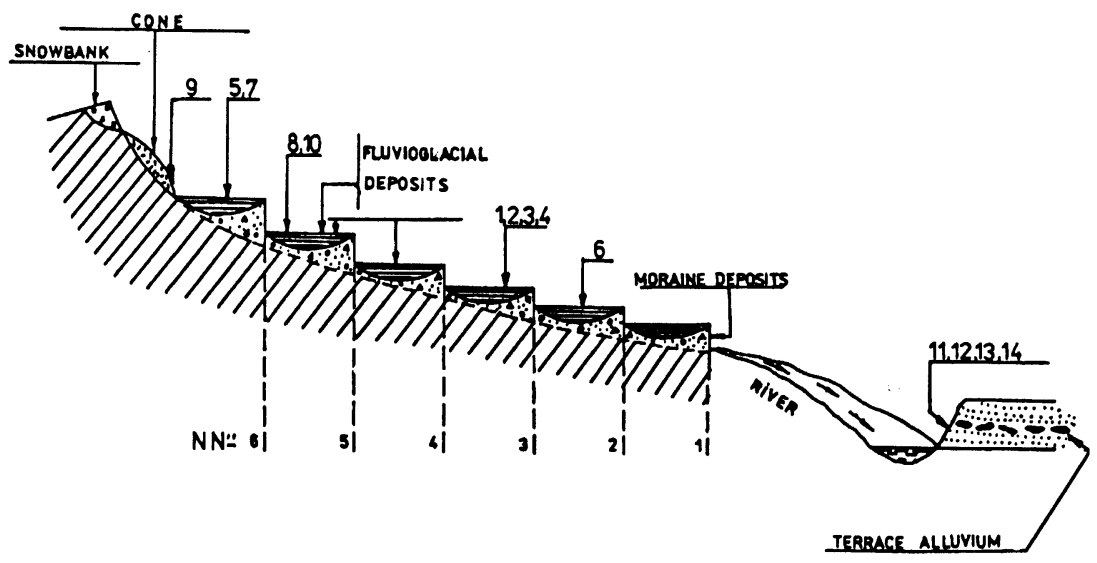

Fig. 4. Profile of the nival-glacial geosystem and correlation of the profiles studied with the stages of end-moraine formation. Figures at the top $=$ profile nos. Figures below $=$ no. of the moraine boundary. Würm maximum according to Tsys (1968): Cone deposit is sediment derived from underneath the snowbank; the moraines were deposited during the Würm. 
1. The modern climatic optimum was preceded by a cold and wet period, from the 11 th to 19 th centuries. This was a period of accumulation of fine-grained sediment at the foot of the cirque (kar) slopes. Deteriorating climate was interrupted by warmer periods, evidenced by layers of buried peat, dated to 540 and $360 \mathrm{yr}$ in Profiles 7 and 9, respectively (Fig. 3).

2. Prior to this most recent period, the second half of the first millennium $B C$ was as warm and favorable for plant growth as at present. The peat layers of Profiles 5, 7 and 9 attest to this regime (Fig. 3).

3. This climate amelioration was preceded by cold and heavy snow, dating to $1.5-2.5 \mathrm{ka}$ (Profiles 4, 5, 7, 9) (Fig. 3). In some highly situated cirques, as for example, in the upper reaches of the river Mria (Fig. 1), embryonic glaciers, fed by sliding snow, deposited glaciofluvial debris into moraines at the lower elevations. Apparently, glacial movement was more active than at present and nival fine-grained sediments were found in Profile 4, at an elevation of $1380 \mathrm{~m}$.

4. A climatic optimum preceded this period, corresponding with a well-documented interruption in glaciation in the Alps (Serebryanny 1978). Dates from the highest profiles, 7 and 9, attest to the lack of glaciers during that period. This was the warmest period in the Carpathians, confirmed by the presence of pine trunks in Profile 1 at a depth of 85-110 m, dated to 27-28 ka. Cryptogamic-palynologic data support these findings. Koziy (1950 or 1968), lacking ${ }^{14} \mathrm{C}$ dates, erroneously assigned this layer to the Middle Holocene climate optimum. Findings of waterlogged sedge meadows rather than wet pine indicated that the climate was drier than at present.

5. The underlying stratum represents a long, cold and wet period, with more active glacial exaration than in subsequent levels. ${ }^{14} \mathrm{C}$ dates of 3.2-4.5 ka correspond to the middle Subboreal. At the time of the 5th and 6th stages of glacial degradation, moraines formed at lower levels, up to $1300 \mathrm{~m}$, as well as glaciofluvial fine-grained sediment.

6. An earlier climatic optimum occurred at $4.5-6 \mathrm{ka}$ in the alpine area, confirmed by dates from Profiles 2, 4 and 6 (Fig. 3). This period fits into the late Subatlantic and early Subboreal and corresponds to the glaciation of the Alps (Serebryanny 1978; Tretyak and Kuleshko 1982) and a 4-6 ka hiatus.

7. The period of 6-10 ka ago was characterized by global morainic, glaciofluvial and nivalfluvial deposition. These events coincide with the regime of the Alps (Tretyak and Kuleshko 1982) during the Atlantic and Boreal periods. In the Carpathians, it was a period of active glacial exaration and moraine formation of the 4th and 5th stages of glacial degradation.

8. A climatic optimum at $10.3-12.3 \mathrm{ka}$ marks the Early Holocene. The warmest phase corresponds to the Allerød, confirmed by peat and wood dates at 12,100 \pm 140 (Profile 6, Fig. 3). It gradually got colder, as evidenced from mare's tail rhizomes found in Profiles 2 and 4.

9. This period was colder, when moraines of the second stage of the post-Würmian glacial degradation formed.

\section{CONCLUSION}

Our results are only preliminary, but they offer firm evidence for a complex landscape history of the Carpathian Mountains. Post-Würmian glacial degradation occurred unevenly over several stages. Many glaciers disappeared by the end of the Würm and reappeared during the Early Holocene. Glacial degradation characterized the early and first half of the Middle Holocene. During the climatic optimum of 4.5-6 ka ago, glaciation disappeared. The youngest moraines may have been formed as late as $2 \mathrm{ka}$ ago during considerable climatic deterioration. Future directions in our research will include cryptogam analyses and comparisons with data from the Ukrainian plains. 


\section{REFERENCES}

Demeduk, N. S. 1975 Quaternary deposits of the Ukrainian Carpathians. Works of the Ukrainian SILRI 25.

Koziy, I. V. (ms.) 1950 Quaternary History of the East Carpathian Forests. Ph. D. dissertation, Lvov University: $30 \mathrm{p}$.

1963 History of flora and vegetation of the Ukrainian Carpathians. In Flora and Fauna of the Carpathians. Moscow, Academy of Sciences of the USSR: 5-15.

Malinovsky, K. A. 1980 Vegetation of the High-Mountainous Region of the Ukrainian Carpathians. Kiev, Naukova Dumka: 280 p.

Miller, L. P. 1961 On the Quaternary glacialization of the Chernogora. Papers and Reports of Lvov State Ukrainian University 9 (2): 179-181.

Serebryanny, L. R. 1978 The Dynamics of Ice Cover and Glaciation in the Late Quaternary Period. Moscow, Nauka: 289.

Stoyko, S. M. and Tretyak P. R. 1979 Modern nival processes in the high-mountainous area of the Chornogora and questions of mountain landscape protection. Papers of the Academy of Science of the USSR 10:81-88.

Tretyak, P. R. 1978 On the role of snow banks in the high-mountainous landscapes of the Ukrainian Carpathians. Papers of the All-Union Geographic Society 110 (3): 142-149.

Tretyak, P. R. and Kuleshko, M. P. 1982 Degradation of the past glaciation in the Ukrainian Carpathians. Papers of the Academy of Sciences of the USSR, Series B (8): 26-31.

Tsys, P. N. 1955 Old glaciation of the Carpathians. Papers and Reports of Lvov State Ukrainian University 6 (2): 6-8.

1968 On geomorphology and neotectonics. In Terenchuk, K. G., ed., Nature of the Ukrainian Carpathians. Lvov Publishing House of Lvov University: 50-86. 